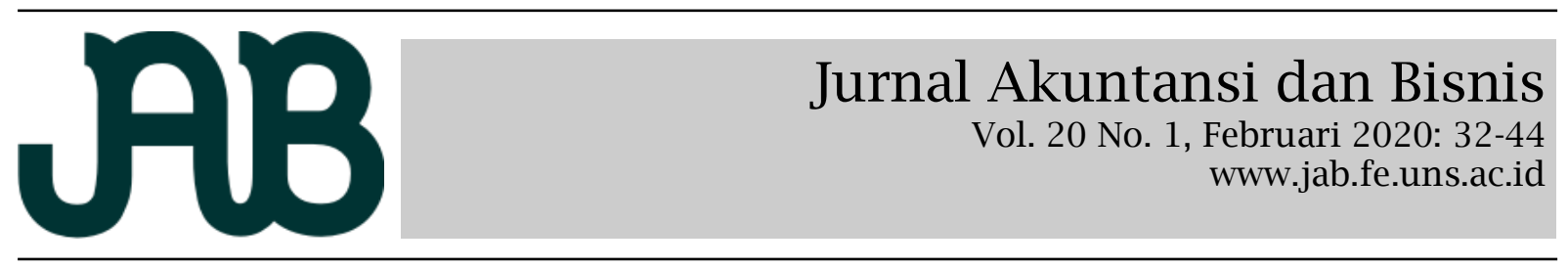

\title{
DETERMINANTS OF INTENTION TO USE SISKEUDES: EXTENDED OF DECOMPOSED THEORY OF PLANNED BEHAVIOR MODEL
}

\author{
ARI KUNCARA WIDAGDOํㅜ (widagdo2002@yahoo.com) \\ SITI ROCHMAH IKA ${ }^{2}$ \\ SENA SATRIA ${ }^{3}$
}

${ }^{1,3}$ Accounting Study Program, Faculty of Economics and Business, Universitas Sebelas Maret, Indonesia ${ }^{2}$ Accounting Study Program, Faculty of Economics, Universitas Janabadra, Indonesia

\begin{abstract}
A B S T R A C T
This study aims to examine factors that influence interest in using the village fund information system (SISKEUDES) by using extended Decomposed Theory of Planned Behavior Model. The respondents are 301 SISKEUDES operators in the Banyumas District. The hypotheses testing uses Partial Least Square (PLS). The result shows that attitude, subjective norms, perception of behavior control, and perceived human resource quality influence the intention to use SISKEUDES. This study demonstrates the appropriateness of the extended Decomposed Theory of Planned Behavior Model in explaining the acceptance of a mandatory system.

Keywords: village fund, financial system, human resource

Penelitian ini bertujuan untuk menguji faktor-faktor yang memengaruhi minat dalam menggunakan sistem informasi dana desa (SISKEUDES) dengan menggunakan extended Decomposed Theory of Planned Behavior Model. Responden adalah 301 operator SISKEUDES di Kabupaten Banyumas. Pengujian hipotesis menggunakan Partial Least Square (PLS). Hasil penelitian menunjukkan bahwa sikap, norma subyektif, persepsi kontrol perilaku, dan persepsi kualitas sumber daya manusia memengaruhi niat untuk menggunakan SISKEUDES. Studi ini menunjukkan kesesuaian extended Decomposed Theory of Planned Behavior Model dalam menjelaskan penerimaan sistem yang bersifat wajib.

Kata kunci: dana desa, sistem keuangan, sumber daya manusia
\end{abstract}

\section{INTRODUCTION}

To improve the quality of village financial governance, in 2015, the Financial and Development Supervisory Agency (Badan Pengawasan Keuangan dan Pembangunan/ BPKP) launched a village financial management system application/software called Sistem Keuangan Dana Desa Village (SISKEUDES) or Village Fund Financial System. Under the Circular of the Ministry of the Interior No. 143/8359/BPD and Letter from the Corruption Eradication Commission No. B.7508/01-16/08/2016 concerning Appeal related to Village/Village Fund Financial Management, this application is mandatory for the village government in managing village fund.

Applying new technology to an organization, both in private and public sectors, is not easy. SISKEUDES implementa- tion also encounters various obstacles. For the application itself, at the beginning of its emergence, there were many problems such as some features not fully functioning and for the features of the Village Fund compilation report and village budget still not per sector. At the district level, the availability of the budget for the provision of training or technical guidance for village officials at the local government level is still deficient, the village task force and clinic for the implementation of SISKEUDES have not been fully formed, while at the village level, the constraints in implementing SISKEUDES are the quality of human resources village equipment that is capable of operating computers is still small and there are still many villages that have not been supplied by electricity networks due to various factors (Jaya, 2018). One exam- 
ple of the problem of lack of quality human resources occurred in Pangandaran District, Pangandaran Regency, West Java, where there is a lack of qualified human resources in each village. Moreover, there is no training or education in advance (Madlani, 2017). Besides that, the implementation of this system takes place when the village fund program has been running, and the villages receiving the village fund are accustomed to managing with manual processes or assist with software such as MS Excel.

Banyumas Regency is one of the districts in Central Java Province. The local village government has received the village fund since 2015. As depicted in Table 1, as of 2015, the amount of Village Funds received has always increased. It can be concluded that the allocation of village funds for Banyumas Regency continues to increase along with the allocation of village funds received by Central Java Province.

Since first receiving village funds until 2017, the village government in Banyumas Regency manages village funds using a manual process with the help of excel software. This manual reporting resulted in a delay in reporting the use of phase 1 (60 percent) village funds in the 2017 fiscal year. As a result, the disbursement of the village fund phase II (40 percent) was delayed until all villages provided reports on the use of their village funds. In addition to the use of manual systems, the low quality of human resources is also one of the obstacles in managing village funds in Banyumas District (Pratiwi \& Ulfah, 2018; Suwarno, 2019). Therefore, the head of Banyumas district decided to use SISKEUDES in the 2018 fiscal year.

Previous studies on technology acceptance and adoption of SISKEUDES have been carried out by several researchers. Most of these prior studies employ a quantitative research approach, while the qualitative research approach is limited. Most of these qualitative prior studies employed the Theory of Acceptance Model (TAM) as a base for developing hypotheses (i.e. Lusiono \& Suharman, 2017; Widagdo \& Setyorini, 2018; Pratiwi \& Pravasanti, 2020). Few prior studies employ other theories such as Delone and Mclean information system success model (Kurnianto, Kurniawansyah \& Ekasari, 2019), and Theory Planned Behavior (TPB) (Salisa, Aeni \& Chamid, 2019). In terms of results, under TAM, some variables indicate mixed findings. For example, some prior studies reveal that perceived ease of use is significantly associated with intention to use SISKEUDES (i.e. Lusiono \& Suharman, 2017; Widagdo \& Setyorini, 2018). In contract, another prior study reveals that such a variable is not significant (i.e. Salisa et al. 2019). In short, previous research was dominated by TAM theory where this theory might not be compatible with the mandatory application of the system.

This study extends the extant literature in two ways. First, this study employs the Decomposed Theory of Planned Behavior (DTPB). DTPB is an extension of TPB proposed by Taylor \& Todd (1995). The development was carried out by providing explanatory factors related to attitudes, subjective norms, and perceived behavioral controls, to provide higher explanatory power and a more accurate understanding of understanding behavior. According to some studies (Taylor \& Todd, 1995; Koeder, Mohammed \& Sugai, 2011; Hsiao \& Tang, 2014; Sundar \& Kanimozhi, 2018), DTPB model provides better diagnostic values than the original TPB model. Besides,

Table 1.

Village Fund Allocation in Period 2015-2017 (in thousand rupiahs)

\begin{tabular}{lrrc}
\hline Year & Banyumas District & Central Java Province & Percentage \\
\hline 2015 & $89,291,645$ & $2,228,889,296$ & 0.0004 \\
2016 & $200,450,575$ & $5,002,426,341$ & 0.0004 \\
2017 & $255,734,553$ & $6,384,442,058$ & 0.0004 \\
\hline
\end{tabular}

Source: Directorate General of Fiscal Balance, Ministry of Finance Indonesia 
this theory has been widely used to evaluate the adoption of different technologies, from the individuals' perspectives rather than an organizational perspective (Kanimozhi \& Selvarani, 2019). Specifically, DTPB might be better able to explain the mandatory use of a system than TAM, because there is a control variable that is perceived behavior control (Rawstorne, Jayasuriya \& Caputi, 2000). Thus, in the context of mandatory acceptance systems such as SISKEUDES, this study argues that DTPB is a more appropriate theory to predict interest than TAM. Second, this study extends the original DPTB by adding the human resource variable. In the acceptance of SISKEUDES, the quality of the village government apparatus is a particular problem, because of the low quality of human resources of the village apparatus (Widagdo \& Setyorini, 2018).

The next section of this paper will present the literature review and development of hypotheses, research methods, results and discussion. The end of this paper presents the conclusions and implications of the study.

\section{LITERATURE REVIEW AND HYPOTHESIS DEVELOPMENT}

\section{Village Financial System (SISKEUDES)}

The village financial system (SISKEUDES) is an accounting information system developed by the Financial and Development Supervisory Agency (BPKP) to improve the quality of village financial governance. SISKEUDES is made very simple and userfriendly, where once the input process followed the transaction, it can directly produce outputs of reports and documents that are following standards and legislation.

The advantages of SISKEUDES applications are following regulations, facilitate village financial management, ease of use of applications, equipped with built-in internal control, and supported by instructions for implementation and application manuals (BPKP, 2016).

\section{Decomposed Theory of Planned Behavior}

Previous studies on technology acceptance and adoption of new technologies use sev- eral theories. At the beginning of the technology acceptance research, the researchers used Theory Reason Action (TRA) developed by Fishbein \& Ajzen (1975). The TRA has various limitations in predicting one's interest in technology acceptance, and then this theory is developed into TAM developed by Davis, Bagozzi \& Warsaw (1989). This theory offers a basis for gaining a better understanding of user behavior in the acceptance and use of information systems (Davis et al., 1989; Venkatesh, Morris, Davis and Davis, 2003), but this theory does not yet provide much insight into why individuals or the group feels dissatisfied. The existence of this deficiency raises a new theory, namely TPB developed by Ajzen (1991). Based on Sundar and Kanimozhi (2018), TAM is easier to use, while TPB provides more information about the factors that users consider when making their choices.

Taylor and Todd (1995) extend TPB, namely DTPB. The development is carried out by providing explanatory factors related to attitudes, subjective norms, and perceived behavioral controls, to provide higher explanatory power and a more accurate understanding of behavior. According to some scholars (Taylor \& Todd, 1995; Koeder et al., 2011; Hsiao and Tang, 2014; Sundar and Kanimozhi, 2018), the DTPB model provides better diagnostic values than the original TPB model and is more complicated, because it introduces several factors that can affect usage of the system. Therefore, DTPB was introduced to overcome some of the limitations in the ТРB model (Nasir, Roslin \& Chui, 2017).

\section{Perceived Ease of Use}

Perception of ease in using technology is an individual's belief that information technology systems are comfortable, not troublesome, and do not require hard effort to use them. Feelings of not requiring hard work in using information technology might foster a feeling that information technology has a function and consequently might create a sense of comfort when working with the information technology system (Venkatesh \& Davis, 2000). Some prior studies (Hsiao \& Tang, 2014; Hwa \& 
Perumal, 2018; Giovanis, Athanasopoulou, Assimakopoulos \& Sarmaniotis, 2019) show that perceived ease of use is an important factor in the prediction of attitude. In the context of SISKEUDES, the operator's perception of the ease of processing data into reports from this system can increase interest in the use of SISKEUDES, so the hypothesis is as follows:

H1a: Perceived ease of use has a positive influence on operators' attitude toward SISKEUDES.

\section{Perceived Usefulness}

Usability perception is a view of future users about the use of the application system whether it can improve its performance or not in every job in the organization (Davis et al., 1989). Understanding the usefulness of information technology might increase the interest of individuals to use it. Previous studies (i.e. Davis, 1989; Teo and Noyes, 2011; Primabudi and Samopa, 2017; Hwa and Perumal, 2018; Giovanis et al., 2019) show that perceived usefulness has a positive and significant effect on attitude. In SISKEUDES, there is a hope that the benefits that might be obtained in the form of improving the performance of village fund management might have a positive effect on the apparatus's interest.

H1b: Perceived usefulness has a positive influence on operators' attitude toward SISKEUDES.

\section{Compatibility}

Hsiao and Tang (2014) define that compatibility is the extent to which innovation from information systems can be integrated with existing values of a potential adopter, previous experience, and current needs. The condition of a person or organization that feels compatible with an information system application based on current experience and needs might encourage the intention to use it. Some prior studies (Hsiao \& Tang, 2014; Primabudi \& Samopa, 2017; Giovanis et al., 2019) reveal that compatibility has a positive and significant effect on the attitude. SISKEUDES, as a system created by the government, might have a high level of compatibility with the needs of village fund management. This might encourage the interests of village government officials. Based on the explanation above, the hypothesis is as follows:

H1c: Compatibility has a positive influence on operators' attitude toward SISKEUDES

\section{Perceived Enjoyment}

Perceived Enjoyment can be defined to what extent the use of information technology is considered enjoyable by the user (Davis et al., 1989). The perception of pleasure has been proposed as the most dominant determinant of attitude in terms of mandatory implementation (Teo \& Noyes, 2011). SISKEUDES will continue to be used by village government officials if the user feels comfortable with all the features. Based on the explanation above, the hypothesis is as follows:

H1d: Perceived enjoyment has a positive influence on operators' attitude toward SISKEUDES.

\section{Peer Influence}

Horizontal relationships occur between individuals and friends or others who are equal (Taylor \& Todd, 1995). In horizontal relationship patterns, expectations are formed descriptively, so the consequence is the desire to imitate or follow (identify) the behavior of others around him (Ajzen, 2005). Some prior studies (Horng-Ji Lai, 2016; Tao \& Fan, 2017; Giovanis et al., 2019) reveal that peer influence is a significant predictor of subjective norms. The influence of peers or friends from other villages who have smoothly used the SISKEUDES application can influence the perception of an operator to use the application. Based on the explanation above, the hypothesis is as follows:

H2a: Peer influences have a positive influence on operators' subjective norms toward SISKEUDES

\section{Superior Influence}

The pattern of a relationship that is above the bottom, raises the perception of demand of hope so that motivation will arise to comply with every demand to do or not to do a behavior (Ajzen, 2005). Horng-Ji Lai (2016) indicates that peer influence and 
superior influence were the primary factors influencing subjective norms. The direction from the Village Head or Regent is very influential in the implementation of SISKEUDES, considering this is a mandatory information system. Based on the explanation above, the hypothesis is as follows:

H2b: Superior influences have a positive influence on operators' subjective norms toward SISKEUDES.

\section{Self-Efficacy}

Self-efficacy is an individual's belief in carrying out certain behaviors (Ajzen, 2002). Individuals will feel more satisfied with the behavior, they feel they can do (Bandura, 1997). Horng-Ji Lai (2016) reveal that selfefficacy appeared to be the most important element determining their perceived behavioral control. The operator's perception of his ability to use SISKEUDES might create positive feelings for using the system. Based on the explanation above, the hypothesis is as follows:

H3a: Self-efficacy has a positive influence on operators' perceived behavior control toward SISKEUDES.

\section{Resource Facilitating Condition}

Resource facilitating conditions reflecting on the level of individual trust that the infrastructure in the organization helps technically to use the system (Venkatesh et al., 2003). Some prior studies (Hsiao \&Tang, 2014; Horng-Ji Lai, 2016; Giovanis et al., 2019) reveal that resource facilitating conditions are significant determinants of perceived behavioral control. The trust and support provided by village government officials give an interest of operators to learn about SISKEUDES. Based on the explanation above, the hypothesis is as follows:

H3a: Resource facilitating condition has a positive influence on operators' perceived behavior control toward SISKEUDES.

\section{Technology Facilitating Condition}

Technology facilitating condition refers to factors in the environment that affect a person's desire to do his work. Teo \& Noyes (2011) find that facilitating conditions are predictors of attitudes toward computer use. With the availability of adequate computers, networks, and electricity from the village government, operators might have positive feelings about using SISKEUDES and believe that using such technology might be relatively free of obstacles. Based on the explanation above, the hypothesis is as follows:

H3c: Technology facilitating condition has a positive influence on operators' perceived behavior control toward SISKEUDES.

\section{Attitudes}

Attitude is a complicated concept and becomes a debate in the social sciences. Ajzen (2005) suggests that attitudes toward this behavior are determined by beliefs about the consequences of behavior or briefly called behavioral beliefs. Belief is related to an individual's subjective assessment of the world around them. Individuals' understanding of themselves and their environment is done by linking certain behaviors with the various benefits or losses that might be obtained if the individual did or did not do it. The results of prior studies (Hsiao and Tang, 2014; Horng-Ji Lai, 2016; Giovanis et al., 2019) show that attitude has a strong, direct, and positive influence on intention. SISKEUDES, as new information technology, can be viewed with a favorable or not attitude. A statement about the ease and benefits of SISKEUDES might provide a favorable attitude, so the hypothesis is as follows:

H4: Operators' attitude has a positive influence on their behavioral intention to use SISKEUDES.

\section{Subjective Norms}

Subjective norms are a social factor, which refers to one's feelings about the way he perceives pressure from the environment to do or not do something or normative values that apply in society (Ajzen, 1991). Some prior studies (Hsiao \& Tang, 2014; Horng-Ji Lai, 2016; Giovanis et al., 2019) indicate that subjective norms are determinants of behavioral intention. The successful use of SISKEUDES in other regions and written instructions from the Minister of the Interior might increase interest in re- 
gions that have not used such a system. Based on the explanation above, the hypothesis is as follows:

H5: Operators' subjective norms have a positive influence on their behavioral intention to use SISKEUDES.

\section{Perceived Behavioral Control}

Perceived behavioral control is reflected in one's experience and also the availability of resources and opportunities (Hsiao and Tang (2014). The stronger a person's belief in the existence of resources and opportunities that someone has concerning behavior and the greater the role, the stronger the perception of one's control over that behavior. Some prior studies (Hsiao and Tang, 2014; Primabudi and Samopa, 2017; Giovanis et al., 2019) reveal that perceived behavioral control has a positive and significant effect on behavior intention. In the context of SISKEUDES, lack of facilities owned by the village government such as the availability of computers, networks, learning, and electricity support can make decreasing interest in using such a system. Based on the explanation above, the hypothesis is as follows:

H6: Operators' perceived behavior control has a positive influence on their behavioral intention to use SISKEUDES.

\section{Perceived Human Resource Quality}

Following Widagdo and Setyorini (2018), perceived human resource quality refers to the user's confidence in his ability to perform certain tasks. The overall ability of individuals consists of two factors, namely intellectual ability and physical ability. The success of using software depends on the technology itself and the level of expertise of the individual who operates. The quality of human resources in the village government is quite low, this condition might make the interest to use SISKEUDES become low, and vice versa (Ariyanti and Alfatih, 2018). Based on the explanation above, the hypothesis is as follows:

H7: Operators' perceived human resource quality has a positive influence on their behavioral intention to use SISKEUDES.

\section{Research Framework}

Based on the explanation above, the research framework is as depicted Figure 1.

\section{RESEARCH METHODS}

The population in this study were all operators of SISKEUDES in the villages in Banyumas District. The sampling method in this study was saturated sampling, where the number of samples was the

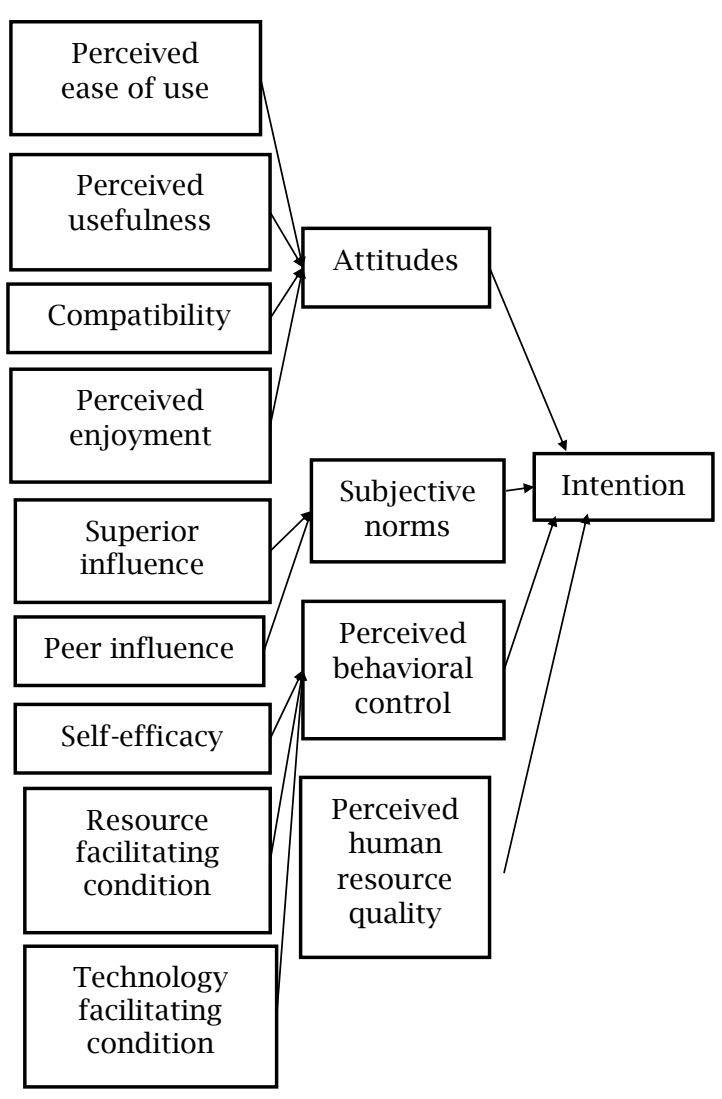

Figure 1.

Research Framework

same as the population (Sugiyono, 2007). The reason for using all the samples was because this study only focused on one district, whereas PLS required a relatively large number of samples. Data was collected through questionnaires that were analyzed by the SmartPLS version 3.0 software program. The questionnaires were directly distributed to 301 operators of SISKEUDES of 301 villages that received village funds in Juli 2018. As can be seen in Table 2, the final sample is 269 respondents. Table 3 presents the research instrument adopted from several prior studies. 


\section{ANALYSIS AND DISCUSSION \\ Respondents Demographic}

Based on Table 4, the sex of respondents is dominated by men (men: 82.90 percent, and women:17.10 percent). In terms of the level of education, it can be seen that most respondents graduate high school (47.96 percent) followed by bachelor (34.20 percent), then diploma (11.52 percent), and lastly junior high school (6.32 percent). Based on age, operators of SISKEUDES in the Banyumas Regency are dominated by the young category (39.03 percent). In terms of the experience of using computers at work, data indicates that more than 85 percent of respondents have sufficient experience in working using computers.

Table 2.

Questionnaire Distribution

\begin{tabular}{lll}
\hline & No & \% \\
\hline Distributed questionnaires & 301 & 100 \\
Unreturned questionnaires & $(23)$ & 7.64 \\
Incomplete questionnaires & $(9)$ & 3.24 \\
Usable questionnaires & 269 & 96.7 \\
\hline
\end{tabular}

\section{Quter Model}

The first step in conducting inferential analysis using SmartPLS is testing the outer model, namely convergent validity, discriminant validity, composite reliability, and average variance extracted (AVE).

\section{Validity and Reliability Test}

In SmartPLS 3.0, to measure the validity of a construct with reflective indicators can be done in two ways, namely the convergent validity value and discriminant validity construct. In terms of convergent validity test, there was one indicator that must be eliminated in the first test, namely the fifth indicator of perceived behavioral control, because it has a value of loading factor $<0.7$ (below the recommended value). In the second test, all items have a loading factor $>0.7$ and the AVE value $>0.5$. Similarly, all items have discriminant validity $>0.7$, which is higher than the recommended value. The results of convergent validity and discriminant validity tests, it can be concluded that all items in this study are valid. In terms of reliability test, this study

Table 3.

Research Instruments

\begin{tabular}{|c|c|c|c|c|}
\hline No & Construct & References & Scale & $\begin{array}{c}\text { Type of } \\
\text { Model }\end{array}$ \\
\hline 1 & Perceived ease of use & Davis et al. (1989) & Five Likert & Reflective \\
\hline 2 & Perceived usefulness & Davis et al. (1989) & Five Likert & Reflective \\
\hline 3 & Compatibility & Davis et al. (1989) & Five Likert & Reflective \\
\hline 4 & Perceived enjoyment & Teo and Noyes (2011) & Five Likert & Reflective \\
\hline 5 & Peer influence & Burnkrant and Page (1988) & Five Likert & Reflective \\
\hline 6 & Superior influence & Burnkrant and Page (1988) & Five Likert & Reflective \\
\hline 7 & Self-efficacy & Ajzen (1985); Ajzen (1991) & Five Likert & Reflective \\
\hline 8 & $\begin{array}{l}\text { Resource facilitating } \\
\text { condition }\end{array}$ & Taylor and Todd (1995) & Five Likert & Reflective \\
\hline 9 & $\begin{array}{l}\text { Technology facilitating } \\
\text { condition }\end{array}$ & Taylor and Todd (1995 & Five Likert & Reflective \\
\hline 10 & Attitude & Taylor and Todd (1995 & Five Likert & Reflective \\
\hline 11 & Subjective norms & Taylor and Todd (1995 & Five Likert & Reflective \\
\hline 12 & $\begin{array}{l}\text { Perceived behavioral con- } \\
\text { trol }\end{array}$ & Taylor and Todd (1995 & Five Likert & Reflective \\
\hline 13 & $\begin{array}{l}\text { Perceived human re- } \\
\text { source quality }\end{array}$ & Marwoto (2012) & Five Likert & Reflective \\
\hline 14 & Intention & Taylor and Todd (1995) & Five Likert & Reflective \\
\hline
\end{tabular}


employed Cronbach's Alpha and composite reliability. The results of the analysis indicate that both the values of Cronbach Alpha and composite reliability are $>0.7$. Therefore, it can be concluded that all constructs are reliable.

\section{Structural Model Testing (Inner Model)}

In the inner model stage, the parameter model used is R-squared $\left(\mathrm{R}^{2}\right)$. The $\mathrm{R}$ squared parameter used to measure the level of variation of the independent variable changes to the dependent variable and the path coefficient to test the significance of the construct in the structural model as indicated by the t-statistics value. The higher $\mathrm{R}^{2}$ means the better the model predicted. $\mathrm{R}$-squared values more than 0.75 show a strong influence, between 0.50-0.75 shows the moderate influence and between 0.250.50 shows a weak influence (Hair, Hult, Ringle, and Sarstedt, 2016).

Based on the results of the $\mathrm{R}^{2}$ in the Table 5, it can be concluded that attitude and perceived behavioral control in this research model have a strong influence to explain the intention to use. Subjective norms have moderate influence. Besides, perceived human resource quality is cate-

Table 4.

Summary of Respondents Profile

\begin{tabular}{llll}
\hline $\begin{array}{c}\text { Demo- } \\
\text { graphic }\end{array}$ & \multicolumn{1}{c}{ Category } & Freq & $\%$ \\
\hline \multirow{2}{*}{ Gender } & Male & 223 & 82.90 \\
& Female & 46 & 17.10 \\
& Junior High & 17 & 6.32 \\
Education & Senior High & 129 & 47.96 \\
& Diploma Degree & 31 & 11.52 \\
& Bachelor Degree & 92 & 34.20 \\
& $20-25$ & 13 & 4.83 \\
Age & $26-30$ & 105 & 39.03 \\
& $31-35$ & 72 & 26.77 \\
& $36-40$ & 76 & 28.25 \\
& 41 above & 3 & 1.12 \\
Experience & $0-5$ & 7 & 2.60 \\
in using & $6-10$ & 142 & 52.79 \\
comput- & $11-15$ & 117 & 43.49 \\
er & $16-20$ & 2 & 0.74 \\
& $21-25$ & 1 & 0.37 \\
\hline
\end{tabular}

gorized as a weak influence. In terms of power explanation of the model, the $\mathrm{R}^{2}$ of intention is 84.1 percent that is categorized also a strong influence. However, this prediction power of the model is slightly lower than the prediction power of the model developed by Widagdo and Setyorini (2018), namely 88.7 percent.

\section{Hypotheses Testing}

The conceptual structural model shows a causal relationship between the constructs in the model. This also includes estimated path coefficients, which show the strength of the hypothesized relationship and the RSquared value that determines the predictive power of the model. The coefficient path and R-Squared indicate how well the data support the hypothesized model.

From the results of the t-statistical test in the Table 6 , it can be seen that the $\mathrm{t}$ statistics and path coefficients of all constructs have a t-statistic value greater than 1.65 and the path coefficient is positive. Thus, as expected, all constructs have a significant and positive influence.

\section{Discussion}

The result indicates that attitude has the strongest influence on operators' behavior intention. This result is consistent with some prior studies (Horng-Ji Lai, 2016; Teo Zhou, and Noyes, 2016). Further analysis indicates that the operators' perceived usefulness of the SISKEUDES is the strongest predictor affecting their attitude. These results suggest that operators believe that SISKEUDES can overcome the difficulties of reporting. As previously noted, the difficulty of manual reporting using MS Excel has caused delays in the disbursement of village funds in phase 2 in Banyumas district. In sum, this finding supports the claim of

Table 5.

R-squared $\left(\mathrm{R}^{2}\right)$ Test

\begin{tabular}{ll}
\hline \multicolumn{1}{c}{ Construct } & \multicolumn{1}{c}{$\mathbf{R}^{\mathbf{2}}$} \\
\hline Attitude & 0.865 \\
Perceived behavioral control & 0.798 \\
Subjective norms & 0.648 \\
Perceived human resource qual- & 0.05 \\
ity & 0.841 \\
Intention & \\
\hline
\end{tabular}


BPKP that the system is useful to assist the village government in managing the village fund because the reports produced are following the standards. This system is also easy to use (user-friendly).

Subjective norms have a positive and significant influence on intention, which is consistent with some prior studies (HorngJi Lai, 2016; Tao \& Fan, 2017). Further analysis indicates that peer influence has a higher influence on subjective norms. This result indicates that the interaction of operators with their colleagues through various forums affects their behavioral intention. Information about the usefulness and convenience of the SISKEUDES from colleagues tends to increase their interest. The relative low of superior influence might indicate that their superiors may not strongly encourage them to use the SISKEUDES, because the superiors themselves are less understanding and familiar with SISKEUDES.

Perceived behavioral control has a significant influence on intention, which is consistent with Giovanis et al. (2019). Resource facilitating condition has the strongest effect on perceived behavior control. It implies that the availability of resources and supporting facilities for the use of SISKEUDES is important. Perceived human resources quality has a significant influence on intention, which is consistent with Widagdo \& Setyorini (2018). However, this finding is not consisting of Widagdo \& Setyorini (2018) that reveal a negative sign of the relation between perceived human resource quality and intention to adopt SISKEUDES. Different research objects might cause different analysis results.

\section{CONCLUSION}

This study intends to examine the determinants of adoption SISKEUDES using extended DTPB. The findings support all of the proposed hypotheses. Behavior intention is significantly explained by attitude, subjective norm, and behavior control. Attitude, in turn, is the most important predictor. This study further suggests that the perceived usefulness of the SISKEUDES played a critical role in predicting the attitude, while the peer influence factor also makes a significant contribution to their subjective norm. The resource facilitating condition, on the other hand, is a key factor affecting their perceived behavior control. This study also evidences that human re-

Table 6.

Coefisient Path Test Results

\begin{tabular}{|c|c|c|c|c|c|}
\hline Cosnstruct & $\begin{array}{c}\text { Original } \\
\text { sample } \\
(0)\end{array}$ & $\begin{array}{c}\text { Sample } \\
\text { mean } \\
(\mathrm{M})\end{array}$ & $\begin{array}{c}\text { Standard } \\
\text { Deviation }\end{array}$ & T-Statistic & $\begin{array}{c}\mathbf{P} \\
\text { Value }\end{array}$ \\
\hline Perceived ease of use $->$ Attitude & 0.303 & 0.308 & 0.049 & 6.241 & 0.000 \\
\hline Compatibility -> Atittude & 0.136 & 0.134 & 0.041 & 3.278 & 0.001 \\
\hline Perceived enjoyment -> Attitude & 0.207 & 0.203 & 0.036 & 5.726 & 0.000 \\
\hline Perceived usefulness -> Attitude & 0.367 & 0.366 & 0.045 & 8.186 & 0.000 \\
\hline $\begin{array}{l}\text { Resource facilitating condition }-> \\
\text { Perceived behavioural control }\end{array}$ & 0.512 & 0,511 & 0.045 & 11.489 & 0.000 \\
\hline $\begin{array}{l}\text { Self-efficacy -> Perceived behaviour- } \\
\text { al control }\end{array}$ & 0.272 & 0,268 & 0.045 & 6.036 & 0.000 \\
\hline $\begin{array}{l}\text { Technology facilitating condition }-> \\
\text { Perceived behavioural control }\end{array}$ & 0.205 & 0,211 & 0.039 & 5.196 & 0.000 \\
\hline Peer influence -> Subjective norms & 0.487 & 0.487 & 0.041 & 12.015 & 0.000 \\
\hline $\begin{array}{l}\text { Superior influence }->\text { Subjective } \\
\text { norms }\end{array}$ & 0.384 & 0,383 & 0.048 & 7.922 & 0.000 \\
\hline Subjective norms -> Intention & 0.209 & 0,209 & 0.046 & 4.585 & 0.000 \\
\hline $\begin{array}{l}\text { Perceived behavioural control } \quad-> \\
\text { Intention }\end{array}$ & 0.312 & 0.312 & 0.068 & 4.613 & 0.000 \\
\hline Attitude -> Intention & 0.290 & 0.292 & 0.072 & 4.041 & 0.000 \\
\hline $\begin{array}{l}\text { Perceived human resource quality -> } \\
\text { Intention }\end{array}$ & 0.161 & 0.158 & 0.056 & 2.898 & 0.002 \\
\hline
\end{tabular}


source quality is a significant factor in adoption SISKEUDES. In short, this study demonstrates the appropriateness of the extended DPTB in explaining the acceptance of a mandatory system.

The results of this study have implications for human resource development management. Banyumas district government needs to carry out a continuous program to increase understanding of the SISKEUDES. Besides, one of the factors causing the high potential for corruption of the village fund is a low understanding of accounting. Therefore, along with the implementation of SISKEUDES, accounting education and training need to be carried out, if necessary, scholarships are provided to send operators to further study in the accounting field. Besides, Banyumas district government needs to create a discussion forum which is a medium for operators to discuss and exchange experience.

\section{LIMITATIONS AND SUGGESTIONS}

There are some limitations to this study. First, this research focuses solely on the determinants of the intention to use SISKEUDES. Further study might consider examining the level of satisfaction of all users of SISKEUDES. Another important issue is to examine the effect of adoption SISKEUDES on financial statements quality of village fund. Second, data collection technique uses questionnaires, so that there is a possible difference between answers given by respondents with actual conditions. Further study might consider applying the mixed-method to overcome this weakness. The mixed-method enables to clarify the result of quantitative analysis by an interview with selected respondents. Third, since this study only focuses on the Banyumas District, the generalization of the findings to other districts might not be applied.

\section{REFERENCES}

Ajzen, I. (1985). From intentions to actions: A theory of planned behavior. In J. Kuhl and J. Beckman (Eds.), Actioncontrol: From cognition to behavior:11 -39. Heidelberg: Springer.

Ajzen, I. (1991). The theory of planned behavior. Organizational Behavior and
Human Decision Processes, 50, 197211.

Ajzen, I. (2002). Perceived behavioral control, self-efficacy, locus of control, and the theory of planned behavior 1 . Journal of Applied Social Psychology, 32(4), 665-683.

Ajzen, I. (2005). Attitudes, personality, and behavior. McGraw-Hill Education (UK).

Ariyanti, A., \& Alfatih, A. (2018). Does the implementation of the Village Financial System (SISKEUDES) program improve the quality of financial reports and village government performance?. Open Access Indonesia Journal of Social Sciences, 1(2), 1-12.

Bandura, A. (1997). Self-efficacy: The exercise of control. H. Freeman: New York, NY.

Burnkrant, R.E., \& Page Jr., T.J. (1988). The structure and antecedents of the normative and attitudinal components of Fishbein's theory of reasoned action. Journal of Experimental Social Psychology, 24(1), 66-87.

Davis, F., Bagozzi, D.R.P., \& Warsaw, P.R. (1989). User acceptance of computer technology: A comparison of two theoretical models. Management Science, 39(8), 983-1003.

Fishbein, M.A., \& Ajzen, I. (1975). Belief, attitude, intention, and behavior: An introduction to theory and research. Reading, MA: Addison-Wesley.

Fishbein, M., \& Ajzen, I. (2005). Theorybased behavior change interventions: Comments on Hobbis and Sutton. Journal of Health Psychology, 10(1), 27-31.

Giovanis, A., Athanasopoulou, P., Assimakopoulos, C., \& Sarmaniotis, C. (2019). Adoption of mobile banking services. International Journal of Bank Marketing, 37(5), 1165-1189.

Hair Jr, J.F., Hult, G.T.M., Ringle, C., \& Sarstedt, M. (2016). A primer on Partial Least Squares Structural Equation Modeling (PLS-SEM). Thousand Oaks, CA: Sage Publications.

Horng-Ji Lai (2016). Examining civil servants' decisions to use Web 2.0 tools for learning, based on the decomposed theory of planned behavior. Interactive Learning Environments, 25 (3), 295-305.

Hsiao, C.H., \& Tang, K.Y. (2014). Explaining undergraduates' behavior intention of e-textbook adoption. Library $\mathrm{Hi}$ Tech, 32(1), 139-163.

Hwa, E.T.B., \& Perumal, S. (2018). Applica- 
tion of Decomposed Theory of Planned Behavior on Retail Patronage amongst Women. International Journal of Academic Research in Business and Social Science, 8(11). 745-757.

Jaya, I. (2018, 8 Februari). Ini kendala implementasi Siskeudes versi BPKP. Diakses dari: http://sinarharapan.net/

Kanimozhi, S., \& Selvarani, A. (2019). Application of the Decomposed Theory of Planned Behavior in technology adoption: A review. International Journal of Research and Analytical Reviews, 6(2), 735-739.

Kanimozhi, S., \& Sundar, S. (2017). Adoption of $4 \mathrm{G}$ mobile services in India: An explanation through Decomposed Theory of Planned Behaviour. Journal of Emerging Technologies and Innovative Research, 4(11), 23-27.

Koeder, M.J., Mohammed, U., \& Sugai, P. (2011). Study of consumer attitudes towards connected reader devices in Japan based on the decomposed theory of planned behavior. Economic and Management Series, EMS-2011, 10.

Kurnianto, S., Kurniawansyah, D., \& Ekasari, W., F. (2019). Menilai keberhasilan sistem keuangan desa (SISKEUDES): Validasi model keberhasilan sistem informasi Delone dan Mclean. Jurnal Riset Akuntansi dan Bisnis Airlangga, 4(2), 687-706.

Lusiono, E.F., \& Suharman, S. (2017). Anlalisis penerimaan aplikasi SISKEUDES di lingkungan pemerintah daerah Kabupaten Sambas. Jurnal Akuntansi, Ekonomi, dan Manajemen Bisnis, 5(2), 163-172.

Madlani. (2017, 16 Januari). Aplikasi sistem keuangan desa di Pangandaran menuai masalah. Diakses dari www.harapanrakyat.com/

Marwoto, N. (2012). Pengaruh kualitas sumber daya manusia (SDM), komunikasi, dan komitmen organisasi terhadap kinerja pegawai Satuan Kerja Perangkat Daerah (SKPD) di lingkungan pemerintah Kabupaten Karimun (Tesis). Universitas Terbuka, Program Sarjana.

Nasir, N.F., Roslin, R.M., \& Chui, C.B. (2017). Decomposing the Theory of Planned Behaviour and incorporating spiritual intelligence to further understand purchase intention of life insurance and takaful. International Journal of Economic Research, 14(16), 241-251.

Pratiwi, D.N., \& Pravasanti, Y.A. (2020). Analisis penggunaan SISKEUDES dalam pengelolaan dana desa. Jurnal Akuntansi dan Pajak, 20(2).

Pratiwi, U., \& Ulfah, P. (2018). Faktor yang mempengaruhi kinerja aparatur pemerintah desa dalam akuntabilitas dana desa. Jurnal Riset Akuntansi dan Keuangan, 6(3), 429-440.

Primabudi, A., \& Samopa, F. (2017). Analysis of factors influencing purchase decision in online store. Case study: Game sales in online store. International Journal of Education and Research, 5(7), 277-288.

Rawstorne, P., Jayasuriya, R., \& Caputi, P. (2000). Issues in predicting and explaining usage behaviors with the technology acceptance model and the theory of planned behavior when usage is mandatory. ICIS 2000 Proceedings. 5.

Salisa, N.R., Aeni, I.N., \& Chamid, A.A. (2019). Analisis faktor-faktor penerimaan penggunaan sistem keuangan desa: Pendekatan TAM dan TPB. Jurnal Ekonomi dan Bisnis, 6(1), 34-53.

Suwarno, S. (2019). Pengelolaan keuangan desa: Perencanaan sampai dengan Pertanggungjawaban pada desa di Kecamatan Cilongok Banyumas. Jurnal Riset Akuntansi dan Perpajakan, 6(01), 25-37.

Tao, C.C., \& Fan, C.C., (2017). A modified decomposed theory of planned behavior model to analyze user intention towards distance-based electronic toll collection services. PrometTraffic\&Transportation, 29(1), 85-97.

Taylor, S., \& Todd, P. (1995). Assessing IT usage: the role of prior experience. MIS Quarterly, 19(4), 561-570.

Teo, T., \& Noyes, J. (2011). An assessment of the influence of perceived enjoyment and attitude on the intention to use technology among pre-service teachers: A structural equation modeling approach. Computers \& Education, 57(2): 1645-1653.

Teo, T., Zhou, M., \& Noyes, J. (2016). Teachers and technology: development of an extended theory of planned behavior. Educational Technology Research and Development, 64(6), 1033-1052.

Venkatesh, V., \& Davis, F.D. (2000). Theoretical extension of the technology acceptance model: Four longitudinal field studies. Management Science, 46 (2), 186-204.

Venkatesh, V., Morris, M.G., Davis, G.B., \& Davis, F.D. (2003). User acceptance of information technology: Toward a 
Determinants of Intention to Use SISKEUDES: Extended of Decomposed Theory of Planned Behavior Model (Widagdo, Ika, dan Satria)

unified view. MIS Quarterly: Management Information Systems, 27(3), 425478.

Widagdo, A.K., \& Setyorini, E. (2018). Deter- minants of intention to use village fund information system. Jurnal Akuntansi dan Keuangan Indonesia, 15(1), 36-58. 
JURNAL AKUNTANSI DAN BISNIS Vol. 20, No. 1, Februari 2020: 32-44

\section{APPENDIX}

\section{Matrix Correlation}

\begin{tabular}{|c|c|c|c|c|c|c|c|c|c|c|c|c|c|}
\hline & PEOU & PU & $\mathrm{CM}$ & PE & PI & SI & SE & RFC & TFC & AT & SN & PBC & HR \\
\hline PEOU & 1 & & & & & & & & & & & & \\
\hline $\mathrm{PU}$ & $0.236^{\text {kit }}$ & 1 & & & & & & & & & & & \\
\hline $\mathrm{CM}$ & $0.194^{\text {*kt }}$ & 0.062 & & & & & & & & & & & \\
\hline $\mathrm{PE}$ & $0.163^{k+k}$ & $0.122^{*}$ & $0.155^{\text {*k }}$ & 1 & & & & & & & & & \\
\hline PI & $0.207^{\text {kit }}$ & $0.184^{*}$ & 0.069 & $0.200^{* * *}$ & 1 & & & & & & & & \\
\hline SI & $0.236^{\text {k* }}$ & $0.113^{*}$ & $0.134^{*}$ & $0.137^{*}$ & $0.297^{* * *}$ & 1 & & & & & & & \\
\hline SE & $0.253^{\text {tik }}$ & $0.130^{*}$ & 0.083 & 0.108 & 0.100 & $0.210^{*}$ & & & & & & & \\
\hline RFC & $0.261^{\text {twat }}$ & 0.109 & $0.225^{\text {** }}$ & $0.151^{\text {*** }}$ & $0.252^{* * k}$ & $0.208^{*}$ & $0.211^{* *}$ & 1 & & & & & \\
\hline $\mathrm{TFC}$ & $0.154^{\text {kit }}$ & 0.079 & $0.135^{*}$ & $0.157^{* * *}$ & 0.060 & $0.187^{*}$ & $0.145^{*}$ & 0.084 & 1 & & & & \\
\hline AT & 0.094 & 0.007 & 0.100 & -0.017 & $-0.127^{*}$ & 0.016 & 0.054 & -0.027 & $0.148^{*}$ & & & & \\
\hline $\mathrm{SN}$ & 0.065 & 0.113 & 0.059 & $0.116^{*}$ & 0.033 & -0.016 & $0.165^{\text {** }}$ & 0.045 & 0.075 & -0.009 & & & \\
\hline $\mathrm{PBC}$ & $0.258^{\text {k* }}$ & $0.228^{*}$ & $0.204^{* *}$ & $0.221^{* *}$ & $0.365^{\text {*** }}$ & $0.281^{*}$ & $0.278^{* * *}$ & $0.336^{* * *}$ & 0.101 & 0.003 & $0.143^{*} 1$ & & \\
\hline HR & $0.297^{\text {knt }}$ & $0.226^{*}$ & $0.197^{* *}$ & $0.230^{* * *}$ & $0.396^{\text {** }}$ & $0.330^{*}$ & $0.349^{* *}$ & $0.408^{* * *}$ & $0.152^{*}$ & 0.012 & $0.158^{*} 0$ & $0.489^{\text {*k }}$ & 1 \\
\hline
\end{tabular}

Notes: AT: Attitude; CM: Compatibility; HR: Human resource; PBC: Perceived behavioral control; PE: Perceived enjoyment; PEOU: Perceived ease of use; PI: Peer influence; PU: Perceived usefulness; RFC: Resource facilitating condition; SE: Self-efficacy; SI: Superior influence; SN: Subjective norms; TFC: Technology facilitating condition 